known to exist in the atmosphere, the active matter of slow dissipation produced from the emanation must be deposited on the surface of all bodies exposed to the open air. The radio-activity observed in ordinary materials is thus probably, in part, due to a thin surface film of radio-active matter deposited from the atmosphere.

A review is given of methods of calculation of the magnitude of the changes occurring in the radio-elements. It is shown that the amount of energy liberated in each radioactive change, which is accompanied by the emission of a particles, is about 100,000 times as great as the energy liberated by the union of hydrogen and oxygen to form an equal weight of water. This energy is, for the most part, carried off in the form of kinetic energy by the $\alpha$ particles.

A description is given of some experiments to see if the $\alpha$ rays carried a positive charge of electricity, with the view of determining experimentally the number of $\alpha$ particles projected from one gram of radium per second. Not the slightest evidence was obtained that the a rays carried a charge at all, although it should readily have been detected. Since there is no doubt that the $a$ rays are deflected in magnetic and electric fields as if they carried a positive charge, it seems probable that the $\alpha$ particles must in some way gain a positive charge after their expulsion from the atom.

Since, on the disintegration theory, the average life of a given quantity of radium cannot be more than a few thousand years, it is necessary to suppose that radium is being continuously produced in the earth. The simplest hypothesis to make is that radium is a disintegration product of the slowly changing elements uranium, thorium, or actinium present in pitchblende. It was arranged that $\mathrm{Mr}$. Soddy should examine whether radium is produced from uranium, but the results so far obtained have been negative.

I have taken solutions of thorium nitrate and the "emanating substance" of Giesel (probably identical with the actinium of Debierne) freed from radium by chemical treatment, and placed them in closed vessels. The amount of radium present is experimentally determined by drawing off the emanation at regular intervals into an electroscope. A sufficient interval of time has not yet elapsed to settle with certainty whether radium is being produced or not, but the indications so far obtained are of a promising character.

\section{RECENT PUBLICATIONS IN AGRICULTURAL} SCIENCE. ${ }^{1}$

THE United States Department of Agriculture has issued the fourth annual instalment of the great work upon which its Division of Soils has embarked, the detailed survey of the soils of the whole of the country. The area covered by the present report is little less than 18 , 0oo square miles, which have been surveyed at a total cost of $12 s$. per square mile. The work is being carried on simultaneously in many parts of the States; the counties dealt with embrace some of the old settled eastern States like New York and New Jersey, the Carolinas and Virginia, the rich lands of Ohio, Kentucky and Illinois, also the recently settled districts in the Dakotas, Texas, Colorado and other areas of deficient rainfall, the Walla Walla wheat area on the Pacific slope, and the lately acquired dependency of Porto Rico.

The method adopted follows that of the earlier reports; a field party maps the distribution of the soils in each section and collects information as to the crops grown and their average yields, the conditions of labour and transportation, at the same time indicating the suitability of the land for new crops and systems of farming. Mechanical analyses of each type of soil are made at Washington and are set out in the report; occasionally chemical analyses are included; statistics of rainfall and mean temperature are also added.

The whole work is based upon' the facts that different types of soil can be recognised and the areas which they 1 "Field Operations of the Division of Soils, roo." By Milton Whitney.
Pp. 842 ; with a case of maps. (Washington: U.S. Department of Agriculture, I903.)

"Monographie Agricole du Pas-de.Calais." By M. Tribordeau. Pp. 296. (Paris: Société d'Encouragement pour l'Industrie Nationale, I90.). (")

Pp. The Journal of the Royal Agricultural Society of England," vol. lxiv. NO. I807, VOL. 70] occupy can be approximately mapped, and that particular crops and systems of farming can be associated with the various soil types, so that the agriculture of each area can be directed along the most appropriate lines and its farmers saved from many unprofitable experiments. While the volume contains no striking novelty, it is full of interest and instruction to the English student of agriculture or economics.

M. Tribordeau gives an account of the agricultural condition of the Pas-de-Calais, dividing it into regions based upon geological considerations of the nature of the subsoil. A description of each soil is given, generally accompanied by several analyses by M. Pagnoul; then follows an account of the agriculture, with reports in considerable detail of the system pursued on one or more farms of different sizes in the area. The varieties of each crop generally grown, the races of live stock, the yield, the conditions of labour, even the implements in use on each farm are carefully set out. The latter half of the volume deals more generally with the agricultural economics of the district, and discusses the position both financial and moral of the labouring class, the conditions of tenure, the societies and other means adopted for the encouragement of agriculture, particularly the spread of the movement for credit banks and cooperative associations. The work is liberally illustrated with maps, photographs and diagrams, and presents a valuable picture of the present critical condition of agriculture in western Europe.

The current volume of the Journal of the Royal Agricultural Society, which now appears annually only, is somewhat more exclusively occupied than usual with the work of the society. In addition to the usual prize lists there is a general account of the show held at Park Royal last June another article on the machinery exhibited there, and a full discussion of the trials of wind pumping engines conducted by the society in 1903. Reports of committees and of the scientific officers of the society also bulk largely, including Dr. J. A. Voelcker's account of the experiments in progress on the farm at Woburn and at the Hills pot-culture station. Turning to the general articles, the interest that is being manifested in forestry is seen in the two opening papers; in one Mr. C. E. Curties treats generally of the management of British woodlands, and in the other Mr. R. Anderson deals with the utilisation of home grown timber and its bye products. Mr. Spencer Pickering describes his experiments at the Duke of Bedford's fruit farm at Woburn, which he has repeated on a different soil at Harpenden, on the ill effects produced by growing grass round apple trees.

The volume is completed by one or two statistical papers and an article by Mr. A. D. Hall on the manuring of grass land, in which he takes the Rothamsted experiments upon grass land as his starting point, and then proceeds to discuss the many other manurial experiments upon hay or pasture which are now in progress in various parts of the country.

\section{MAIDSTONE MEETING OF THHE SOUTH-}

\section{EASTERN UNION OF SCIENTIFIC SOCIE TIES.}

THE ninth annual congress of the South-eastern Union of Scientific Societies opened on the evening of June 9, when Sir Henry Howorth, the outgoing president, resigned his seat to Mr. Henry Rudler, who delivered the annual address at the Town Mall, Maidstone.

Mr. Rudler alluded to his address as a string of commonplaces, but in it some very important topics were touched upon. He considered, for instance, the constitution of scientific societies, and the matters to be discussed at their meetings in these days of great specialisation. He divided the members of such societies as constitute the union into those (few in number) who do the work and those (the majority) who like to see what is being done. Mr. Rudler was of opinion that the latter should have their wants realised as well as the specialists, for to put it on the lowest plane, the societies generally depended upon the financial support of those intellectual people who take a general interest in the progress of science without aiding in it themselves. Mr. Rudler's advice was to hold sectional meetings for the specialists, where the matters to be considered might be as technical as occasion required, and to 
arrange general meetings where scientific subjects were dealt with in a popular manner. The fact had to be remembered that many of the members came to the meetings after working hard all day, and with their brains more or less exhausted and in need of recreation.

Mr. Rudler also dealt with the craze for athleticism, which tended to lessen the ranks of the local societies and even of the British Association itself. He said that a party on a field excursion would get more physical benefit than a crowd of spectators watching competitions between professional athletes. "He contended that the taste for "sport" of to-day was only a part of a large subject, the excessive love of pleasure. He said that different people had different ideas with regard to recreation, but that those who turned to natural history were exceptionally wise in their choice. Parents, and especially ladies, would, he suggested, do well to join a natural history society, if only as an example for the young, and to introduce them to a healthy atmosphere. Now that nature-study was successfully edging its way into our schools, there should be a fine crop of young naturalists in the making, and Mr. Rudler told the societies not to wait for the students to grow up, but to found branches for junior members.

After saying a word as to the secondary place that the results of the camera and the magic lantern should take in popuiar lectures, Mr. Rudler passed on to speak of the scientific work done by Maidstone men in the past, and to congratulate the town upon its museum.

On the morning of June Io business was transacted, and officers and committee elected "For the Photographic Record and Survey of Kent," after a report of the work of the provisional committee had been read by $\mathrm{Mr}$. $\mathrm{H}$. Snowden Ward, who had acted as organising secretary.

Mr. F. J. Bennett, in a short paper, pointed out that the Kentish megaliths, like those in Wiltshire, follow lines which run from north to south, and this is also true in the case of earthworks and churches. A paper on the Lepidoptera of mid-Kent, by Captain Saville G. Reid, was taken as read, and the meeting concluded with some excellent suggestions by $\mathrm{Mr}$. Bennett with regard to the utilisation of the twenty-five inch Ordnance maps by farmers. On these a plan of the drainage, the arrangements for which are often completely forgotten, could be entered, together with details of the work carried on from year to year. Mr. Bennett urged that such work should be secured by legislation, and the suggestion met with cordial approval. On the afternoon of June io there were two excursions; the first-geological and archæologicalwas to Aylesford, under the leadership of $\mathrm{Mr}$. Whitaker and Mr. W. H. Benstead. The second was of a botanical and entomological character to the North Downs, under the leadership of Prof. Boulger, Captain Reid, and Mr. Elgar. In the evening the Mayor and Mayoress (Alderman and Mrs. Morling) held a reception in the Museum, Art Gallery and Technical Schools, which adjoin one another in a very convenient way. Afterwards the visitors had an opportunity of examining the Congress Museum, which consisted of specimens sent by members of affiliated societies, and arranged by Mr. E. W. Swanton. There were also on view nature-study exhibits from Kent schools to illustrate the paper to be read on the following morning. During the evening Mr. A. B. Harding read a paper on "Ice Streams and Ice Caves," and Mr. Paul Matthews described the possibilities of an artificial language, and gave an explanation of that which is known as "Esperanto."

On June in the election of officers took place. Prof. Flinders Petrie was elected president, and Dr. Abbott, to whom the union owes its origin, exchanged his office of honorary secretary with the Rev. R. Ashington Bullen for that of treasurer, which the latter occupied. The two vacancies on the council were filled with Miss Lawrence, of Reigate, and Mr. Wilfred Mark Webb.

When the last paper, which was on "The Teaching of Nature-study," was read by Mr. Wilfred Mark Webb, a number of teachers and pupil teachers were present through the efforts of the Kent County Education Committee and the local committee of the congress. Considerable discussion took place afterwards. Sir Henry Howorth supported the aim that the pupil should be made to ask why and to find out the answer for himself, and dwelt for some time on the advisability of studying animals in captivity.
Prof. Boulger thought that nature-study should, in the case of young children, be correlated with poetry. Mr. Tutt pointed out the difficulties that occur in town schools, and urged the claims of more formal work than had been outlined, which savoured somewhat of science teaching. Mr. J. B. Groom, of St. Paul's Schools, Maidstone, who has made a speciality of rambles, begged the young teachers present to follow informal lines rather than those advocated by Mr. Tutt.

The number of societies now affiliated is forty-three, with upwards of five thousand members, while the funds of the union are in a satisfactory condition, and an invitation has been accepted to visit Reigate during 1905.

\section{EDUCATIONAL CONFERENCE AT THE HORTICULTURAL EXHIBITION.}

$\mathrm{O}^{\mathrm{N}}$ June 7 a conference was held at the Royal Botanic Gardens, Regent's Park, in connection with the educational section of the Horticultural Exhibition, which was open during the whole of last week.

Sir William J. Collins, chairman of the Education Committee of the London County Council, and president of the section, took the chair, and Mr. F. W. Verney read a paper on "Allotment Gardens and Working Men." In the course of this a good deal of stress was laid upon the need for teaching which would prepare country boys to work on the land, and a scheme for their education was mapped out. It seems to be generally recognised that if a boy is ever to do much good on a farm he must become acquainted with its working at an early age, and the compromise desired by Mr. Verney that a boy should be allowed to do some practical work on a farm before his school days are over would not only satisfy practical requirements, but would also probably keep the pupils under the influence of the schoolmaster for a longer period than is at present the case.

Miss Lilian Clark afterwards read a paper upon "Direct Methods of Studying Nature," such as are employed at the James Allen School for Girls, Dulwich. The papers which Miss Clark has read in the past at various science conferences have made us familiar with her work in garden and classroom, where real plants and not books are studied. It is interesting to be able to chronicle that a special room, which is a combination of laboratory and greenhouse, has been built as an aid to the experiments and observations which she directs.

Later in the morning Sir George Kekewich, who is president of the School Nature Study Union, gave an address on "Nature-study and its Cognate Educational Subjects." $\mathrm{He}$ made a special point of nature-study as a part of general education, saying that he would like to see it taught in every school in this country. The kind of training outlined was that now generally recognised as being really nature-study, and as Sir George Kekewich is one of those who think that the work, to be done properly, should be carried on out of doors, he spoke of the great difficulties which must exist in the case of most town schools. These difficulties would be all the greater if teachers felt, as Sir George Kekewich seems to do, that to keep animals in captivity (Sir George afterwards excepted canaries) is calculated to teach cruelty.

In the discussion the speakers were practically unanimous in disagreeing with the contention last alluded to. $\mathrm{Mr}$. Hedger Wallace (honorary secretary of the section), Miss Kate Hall, and Miss Von Wyss were among those who thought that many animals could be properly studied "under control." The present writer expressed his opinion that as children see plenty of cruelty in their everyday life, it would be advisable to teach them kindness by keeping pets, and that if this were not done in nature-study, a great power for good would be thrown away.

Sir William Collins summed up nature-study; he said that it was not a new subject, though its recognition and the enthusiasm for it were new, and he emphasised the fact alluded to by Sir George Kekewich that it was not science teaching.

The opinion expressed by Sir George Kekewich that nature-study would not stay the rural exodus, and that its far-reaching effects would not be felt until other means

NO. I807, VOL. 70] 